\title{
KARAKTERISTIK DAN ORIENTASI KURIKULUM PENDIDIKAN ISLAM
}

\author{
Ach. Nurholis Majid
}

\section{A. Pendahuluan}

Pendidikan bisa jadi sebuah kartu remi, seseorang bisa menebaknya dari rencana-rencana definitif bernama kurikulum. Sebab, ramalan atas pendidikan begitu erat kaitannya dengan kurikulum. Ia menjadi semacam penentu bagi arah perkembangan pendidikan. Bahkan tujuan pendidikan tidak akan tercapai tanpa keterlibatan kurikulum pendidikan.

Kurikulum menjadi suatu kausal, bahwa jika wujudnya baik, maka output dari suatu pendidikan akan baik pula. Demikian sebaliknya. Jika seperti itu, maka posisi kurikulum tidak boleh tidak, harus dipersiapkan secara matang.

Persiapan itu setidaknya titandai dengan begitu dinamisnya kurikulum pendidikan di Indonesia. Sehingga tidak mengherankan jika telah ada sebelas kali perubahan kurikulum di Indonesia sejak tahun 1947, 1952, 1964, 1968, 1975, 1984, 1994, 1999, 2004, 2006, 2013.

Walaupun banyak orang merasa sinis-atau lebih tepatnya menganggap ada muatan politik - terhadap intesitas perubahan kurikulum tersebut. Tetapi yang terpenting adalah keyakinan bahwa, kurikulum tetap merupakan program dalam mencapai tujuan pendidikan ${ }^{1}$.

Tujuan pendidikan yang berdasarkan kehendak manusia yang membuat kurikulum itu sendiri. Kehendak manusia, siapa pun, di mana pun, sama, yaitu menghendaki terwujudnya manusia yang baik ${ }^{2}$.

Karena begitu pentingnya kurikulum dalam menentukan kualitas pendidikan, maka tulisan ini memusatkan perhatian pada karakter dan orientasi kurikulum pendidikan Islam, yang selama ini diyakini paling syumul (mencakup) dalam mempersiapkan pendidikan yang berkualitas.

Untuk mencapai pengertian yang baik, maka tulisan ini akan membahas definisi kurikulum pendidikan Islam, karakter kurikulum pendidikan Islam dan orientasi pendidikan Islam.

\section{B. Hakikat Kurikulum Pendidikan Islam}

Sejalan dengan sifat kurikulum, definisinya pun mengalami perkembangan yang progresif. Tetapi beberapa pengertian akan diambil untuk mendekati pengertian yang lebih tepat. Kurikulum bisa dimaknai sebagai totalitas pengalaman dan kegiatan yang diselenggarakan oleh sekolah-di bawah pengawasan guru-agar terjadi komunikasi antara guru dan murid. Sehingga dengan itu, terjadi proses pendidikan dan perubahan perilaku yang berpengaruh pada pertumbuhan yang komplit dan sempurna (kamil). Pengertian ini tidak terbatas pada buku teks, tetapi meluas pada banyak unsur yang diantaranya adalah rencana pendidikan, metode pengajaran, sikap

\footnotetext{
${ }^{1}$ Ahmad Tafsir, Filsafat Pendidikan Islami, (Bandung: Remaja Rosdakarya, 2010), 99.

${ }^{2}$ Ibid., 100
} 
pendidikan, kegiatan di dalam dan di luar kelas, termasuk juga di luar lingkungan sekolah, untuk mencapai tujuan dan fungsi pendidikan dan kehidupan sosial. $^{3}$

Pengertian yang lain ditawarkan oleh Ronald C. Doll, bahwa kurikulum merupakan pengalaman yang ditawarkan kepada anak didik di bawah bimbingan dan arahan sekolah. berikut: ${ }^{5}$

Jika dilihat menurut fungsinya, kurikulum dapat juga diartikan sebagai

1. Kurikulum sebagai program studi. Pengertiannya adalah seperangkat mata pelajaran yang mampu dipelajari oleh peserta didik di sekolah atau di institusi pendidikan lainnya.

2. Kurikulum sebagai konten. Pengertiannya adalah data atau informasi yang tertera dalam buku-buku kelas tanpa dilengkapi dengan data informal lain yang memungkinkan timbulnya belajar.

3. Kurikulum sebagai kegiatan terencana. Pengertiannya adalah kegiatan yang direncanakan tentang hal-hal yang akan diajarkan dan dengan cara bagaimana hal itu dapat diajarkan dengan berhasil.

4. Kurikulum sebagai hasil belajar. Pengertiannya adalah seperangkat tujuan yang utuh untuk memperoleh suatu hasil tertentu tanpa menspesifikasikan cara-cara yang dituju untuk memperoleh hasil itu, atau seperangkat hasil belajar yang direncanakan dan diinginkan.

5. Kurikulum sebagai reproduksi kultural. Pengertiannya adalah transfer dan refleksi butir-butir kebudayaan masyarakat, agar dimiliki dan dipahami anak-anak generasi muda masyarakat tersebut.

6. Kurikulum sebagai pengalaman belajar. Pengertiannya adalah keseluruhan pengalaman belajar yang direncanakan di bawah pimpinan sekolah.

7. Kurikulum sebagai produksi. Pengertiannya adalah seperangkat tugas yang harus dilakukan untuk mencapai hasil yang ditetapkan terlebih dahulu.

Dilihat dari fungsi dan tujuannya, maka kurikulum merupakan suatu kegiatan yang mencakup berbagai rencana kegiatan peserta didik yang terperinci berupa bentuk-bentuk bahan pendidikan, saran-saran strategi belajar-mengajar, pengaturan-pengaturan program agar dapat diterapkan, dan hal-hal yang mencakup pada kegiatan yang bertujuan mencapai tujuan yang diinginkan.

Tujuan pendidikan yang diinginkan bisa saja beragam, sebagaimana Ahmad Tafsir dalam Filsafat Pendidikan Islami meniscayakan produk

\footnotetext{
${ }^{3}$ Saad A, Hajatuna Ila Manahij Islamiah, diakses dari http://www.saaid.net/manahej/17.htm pada tanggal 02 Oktober 2015 pukul 21.52.

${ }^{4}$ Ronald C Dolls, Curriculum Improvement: Decision Making and Process, (Boston: Allyn \& Bacon, 1974), 22.

${ }^{5}$ Muhammad Ansyar, Dasar-Dasar Pengembangan Kurikulum, (Jakarta: Dirjen PT-PPLPTK Depdikbut, 1089), 8-20.

${ }^{6}$ Abdul Mujib dan Jusuf Mudzakir, Ilmu Pendidikan Islam, (Jakarta: Kencana Prenada Media Group, 2008) 123.
} 
manusia yang baik". Sedangkan Ahmad Dahlan mengharapkan keimanan dan amal salih yang khas. ${ }^{7}$

Tetapi yang perlu digarisbawahi, kurikulum Pendidikan Agama Islam adalah rumusan tentang tujuan, materi, metode dan evaluasi pendidikan yang bersumber pada ajaran agama Islam. ${ }^{8}$

Penting untuk melihat pengertian ini, sebagai identitas bahwa pendidikan Islam bukan sekedar materi ajar agama Islam, tetapi juga terintegrasinya nilai-nilai islami dalam kurikulum yang dibuat.

Sehingga nilai-nilai islami benar-benar menjadi acuan dalam proses pendidikan, sebagaimana pengertian yang disampaikan Zakiyah Daradjat bahwa, pendidikan agama Islam adalah suatu usaha untuk membina dan mengasuh peserta didik agar senantiasa dapat memahami ajaran Islam secara menyeluruh. ${ }^{9}$

Tetapi, dalam pengertian kurikulum ini, hampir semua ahli sepakat bahwa, kurikulum merupakan suatu program yang berkaitan dengan perencanaan, proses, pelaksanaan dan evaluasi dalam pendidikan.

\section{Karakteristik Kurikulum Pendidikan Islam}

Salah satu karakter dari kurikulum pendidikan Islam adalah pelestariannya terhadap nilai-nilai keislaman dengan tetap berpegang teguh pada konsep futuristic (ijtihad). Sebab jika tidak, maka kurikulum pendidikan Islam hanya akan berfungsi sebagai "agent of conservative". Padahal lebih dari itu, kurikulum lebih diharapkan menjadi "agent of change".

Artinya, nilai-nilai yang bersifat universal dan objektif (nilai ilahiah) secara intrinsik tetap dilestarikan sampai generasi-generasi berikutnya. Namun, konfigurasinya dapat dikembangkan sesuai dengan tuntutan zaman, keadaan dan tempat. Sebaliknya, nilai lokal yang bersifat subjektif (nilai insaniah), baik intrinsik maupun konfigurasinya, dapat diubah menurut perkembangan yang diinginkan dengan syarat tidak menimbulkan keresahan dan kebingungan masyarakat. ${ }^{10}$

\section{Dasar-Dasar Pokok dalam Kurikulum Pendidikan Islam}

Untuk itu, al-Syaibani menetapkan empat dasar pokok dalam kurikulum pendidikan Islam, yaitu dasar religi, dasar falsafah, dasar psikologis, dasar sosiologis dan dasar organisatoris. ${ }^{11}$

Dasar religi merupakan dasar yang dikonstruksi dari nilai-nilai ilahiah yang terkandung dalam Al-Quran dan As-Sunnah, serta sumber dalil ijtihadi yang tidak berlawanan dengan jiwa dan semangat dua pedoman di atas.

Dasar ini, sesuai dengan sabda Nabi SAW. "Sesungguhnya aku telah meninggalkanuntukkamu, yang jika kamu berpegang teguh

\footnotetext{
${ }^{7}$ Ahmad Tafsir, Filsafat. 215.

${ }^{8}$ Abdul Majid, dan Dian Andayani, Pendidikan Agama Islam Berbasis Kompetensi. (Bandung: Remaja Rosda Karya, 2006), 74.

${ }^{9}$ Ibid., 130.

${ }^{10}$ Abdul Majid, dan Dian Andayani, Pendidikan. 136.

${ }^{11}$ Ibid., 124.
} 
dengannya, maka kamu tidak akan tersesat selama-lamanya, yakni kitabullah dan Sunnah Nabi-Nya” (HR. Hakim). ${ }^{12}$

Dasar Falsafah, dasar ini memberikan arah tujuan pendidikan dengan pertanyaan apakah susunan kurikulum pendidikan telah mengandung suatu kebenaran, terutama kebenaran di bidang nilai-nilai sebagai way of life yang diyakini kebenarannya.

Dasar Psikologis, dasar psikologis merupakan dasar yang berkaitan dengan kemampuan anak didik dalam menerima dan mempraktikkan pengetahuan serta pemberian apa saja yang menjadi kebutuhan anak didik. Dalam hal ini Nasution membaginya kedalam "psikologi pelajar" dan "psikologi anak", yang penjabarannya tidak jauh beda, yakni hakikat pembelajaran kepada pelajar dan pemenuhan kebutuhan dan kepentingan anak.

Dasar sosiologis, dasar ini memberikan implikasi bahwa kurikulum pendidikan memegang peranan penting terhadap penyampaian dan pengembangan kebudayaan, proses sosialisasi individu, dan rekonstruksi masyarakat, walaupun tidak ada kepastian bentuk masyarakat yang bagaimana yang ingin direkonstruksi. ${ }^{13}$

\section{Prinsip dan Fungsi Kurikulum Pendidikan Islam}

Menurut Syaibani juga, prinsip utama dalam kurikulum pendidikan Islam setidaknya ada tujuh prinsip.

1. Berorientasi pada Islam, termasuk ajaran dan nilai-nilainya. Adapun kegiatan kurikulum yang baik berupa falsafah, tujuan, metode, prosedur, cara melakukan, dan hubungan-hubungan yang berlaku di lembaga harus berdasarkan Islam.

2. Prinsip meyeluruh (syumuliah) baik dalam tujuan maupun isi kandungannya.

3. Prinsip keseimbangan (tawazun) antara tujuan dan kandungan kurikulum.

4. Prinsip interaksi (ittishaliyah) antara kebutuhan siswa dan kebutuhan masyarakat.

5. Prinsip pemeliharaan (wiqayah) antara perbedaan-perbedaan individu.

6. Prinsip perkembangan (tanmiyah) dan perubahan (taghayyur) seiring dengan tuntutan yang ada dengan tidak mengabaikan nilai-nilai absolut Ilahiyah, dan

7. Prinsip integritas (muwahhadah) antara mata pelajaran, pengalaman, dan aktivitas kurikulum dengan kebutuhan peserta didik, masyarakat, dan tututan zaman, tempat peserta didik berada.

\section{Orientasi Pendidikan Agama Islam terhadap Kurikulum}

Pada dasarnya, kurikulum pendidikan seringkali berorientasi pada lima hal, yaitu orientasi pada pelestarian nilai-nilai, orientasi pada kebutuhan sosial,

${ }^{12}$ Ibid., h. 125.

${ }^{13}$ Abdul Majid dan Dian Andayani, Pendidikan. 130-131 
orientasi pada tenaga kerja, orientasi pada peserta didik, dan orientasi pada masa depan dan perkembangan ilmu pengetahuan dan teknologi. ${ }^{14}$

\section{Orientasi Pelestarian Nilai}

Dalam pandangan Islam, nilai terbagi atas dua macam, yaitu nilai yang turun dari Allah SWT, yang disebut nilai ilahiyah, dan nilai yang tumbuh dan berkembang dari peradaban manusia sendiri yang disebut dengan nilai insaniyah. Kedua nilai tersebut selanjutnya membentuk norma-norma atau kaidah-kaidah kehidupan yang dianut dan melembaga pada masyarakat yang mendukungnya. Tugas kurikulum selanjutnya adalah menciptakan situasi-situasi dan program tertentu untuk melestarikan kedua nilai tersebut.

\section{Orientasi pada Kebutuhan Sosial}

Ibnu Taimiyah dalam rangkaian pemikirannya menyatakan bahwa, untuk menciptakan keadilan sosial, perlu diadakan penekanan tugas-tugas manusia sebagai makhluk sosial yang mengemban kewajiban kolektif untuk menciptakan kesejahteraan bersama, bukan sekedar makhluk individu dengan tugas-tugas individualnya. ${ }^{15}$

Penekanan atas kewajiban kolektif di atas, merupakan sarana munculnya berbagai peradaban dan kebudayaan yang terorganisir dan demonstartif. Sehingga masyarakat mengalami perubahan dan perkembangan yang pesat walaupun perkembangan itu tidak mencapai pada titik kulminasi. Hal ini Karena kehidupan adalah perkembangan, tanpa perkembangan berarti tidak ada kehidupan.

\section{Orientasi pada Tenaga Kerja}

Manusia sebagai makhluk biologis mempunyai unsur mekanisme jasmani yang membutuhkan kebutuhan-kebutuhan lahiriah, misalnya makan minum, bertempat tinggal yang layak, dan kebutuhan biologis lainnya. Kebutuhan-kebutuhan tersebut harus terpenuhi secara layak, dan salah satu di antara persiapan untuk mendapatkan pemenuhan kebutuhan yang layak adalah melalui pendidikan.

Dengan pendidikan, pengalaman dan pengetahuan seseorang bertambah dan dapat menentukan kualitas dan kuantitas kerja seseorang. Hal ini karena dunia kerja dewasa ini semakin banyak saingan, dan jumlah perkembangan penduduk jauh lebih pesat dari penyediaan lapangan kerja.

Sebagai konsekuensinya, kurikulum pendidikan diarahkan untuk memenuhi kebutuhan kerja. Hal ini ditujukan setelah keluar dari lembaga sekolah, peserta didik mempunyai kemampuan dan keterampilan yang profesional, berproduktif dan kreatif, mampu mendayagunakan sumber daya alam, sumber daya diri dan sumber daya situasi yang mempengaruhinya.

Tetapi dalam kurikulum pendidikan Islam, orientasi ini tidak boleh berjalan sendiri, ia harus diiringi dengan moralitas yang tepat. Sebab kenyataannya, output yang siap pakai tidak serta merta memberi

\footnotetext{
${ }^{14}$ Abdul Mujib dan Jusuf Mudzakir, Ilmu. 135.

15 Amien Rais M., Cakrawala Islam, antara Cita dan Fakta, (Bandung: Mizan, 1991), 119.
} 
perubahan yang positif. Terutama karena tidak terbinanya sikap mental sebagai "manusia yang baik".

Pada masa Yunani Kuno, pendidikan memang diadakan bukan untuk menyiapkan tenaga kerja. Pendidikan diadakan dengan tujuan untuk lebih memanusiakan manusia, agar derajat manusia menjadi lebih tinggi sekurang-kurangnya lebih tinggi daripada binatang. ${ }^{16}$

\section{Orientasi pada Peserta Didik}

Orientasi ini memberikan kompas pada kurikulum untuk memenuhi kebutuhan peserta didik yang disesuaikan dengan bakat, minat, dan potensi yang dimilikinya, serta kebutuhan peserta didik. Orientasi ini diarahkan kepada pembinaan tiga dimensi peserta didiknya.

\section{E. Kesimpulan}

Keberadaan kurikulum merupakan dasar untuk berdirinya bangunan pendidikan yang kokoh. Dengan demikian, kurikulum harus dipersiapkan dengan sebaik mungkin. Karena pertaruhannya adalah kualitas peserta didik, kehidupan sosial, dan kebudayaan yang dihasilkan oleh proses pendidikan itu sendiri.

Hampir semua ahli sepakat bahwa, kurikulum merupakan suatu program yang berkaitan dengan perencanaan, proses, pelaksanaan dan evaluasi dalam pendidikan.

Secara kegunaan, kurikulum bisa dilihat dari fungsinya sebagai program studi yang kaitannya erat dengan perangkat pendidikan, sebagai konten yang kaitannya dengan materi pendidikan, sebagai kegiatan terencana yang diformulasikan dalam master plan pendidikan. Kurikulum sebagai hasil rencana, yang erat kaitannya dengan tujuan pendidikan.

Selain itu, kurikulum juga berfungsi sebagai reproduksi kultural, dengan kegiatan transfer dan refleksi kebudayaan masyarakat. Kurikulum juga berfungsi sebagai pengalaman belajar, yang keberadaannya merupakan seluruh pengalaman belajar yang direncanakan oleh kepala sekolah. Terakhir, kurikulum sebagai produksi yang menyangkut seperangkat tugas, untuk menghasilkan output sebagaimana direncanakan terlebih dahulu dalam fungsi rencana.

Kurikulum dengan pengertian dan fungsinya, kemudian diharapkan menghasilkan "manusia yang baik" sebagaimana disampaikan Ahmad Tafsir, dan diharapkan memiliki keimanan dan amal salih yang khas sebagaimana konsep pembaharuan yang diusung oleh Ahmad Dahlan.

Tetapi yang perlu digarisbawahi, kurikulum Pendidikan Agama Islam adalah rumusan tentang tujuan, materi, metode dan evaluasi pendidikan yang bersumber pada ajaran agama Islam. Ajaran agama Islam yang dimaksud bukan sekedar materi ajar agama Islam, tetapi juga terintegrasinya nilai-nilai islami dalam kurikulum yang dibuat.

Dengan pengertian itu, kurikulum pendidikan Islam dibangun di atas prinsip-prinsi kurikulum pendidikan Islam yang diantaranya adalah orientasi

${ }^{16}$ Ahmad Tafsir, Filsafat. 130. 
pelestarian nilai-nilai dan ajaran Islam baik berupa falsafah, tujuan, metode, prosedur, cara melakukan, dan hubungan-hubungan yang berlaku di lembaga harus berdasarkan Islam.

Kedua, prinsip meyeluruh (syumuliah) baik dalam tujuan maupun isi kandungannya. Syumuliah yang didasarkan atas keseimbangan (tawazun) antara tujuan dan kandungan kurikulum, agar terjadi interaksi (ittishaliyah) antara kebutuhan siswa dan kebutuhan masyarakat.

Adanya pemeliharaan (wiqayah) antara perbedaan-perbedaan individu, dengan melihat perkembangan (tanmiyah) dan perubahan (taghayyur) seiring dengan tuntutan yang ada dengan tidak mengabaikan nilai-nilai absolut Ilahiyah.

Terakhir prinsip yang terkandung dalam kurikulum pendidikan Islam adalah integritas (muwahhadah) antara mata pelajaran, pengalaman, dan aktivitas kurikulum dengan kebutuhan peserta didik, masyarakat, dan tututan zaman, tempat peserta didik berada.

Atas dasar prinsip itu, maka orientasi kurikulum pendidikan Islam adalah orientasi pelestarian nilai, orientasi pada kebutuhan sosial, orientasi pada tenaga kerja, serta orientasi pada peserta didik.

Yang menjadi perbedaan kurikulum pendidikan Islam dengan yang lainnya, adalah nilai yang ingin ditanamkan dalam prosesnya. Bahwa kurikulum pendidikan Islam harus berlandaskan nilai-nilai Islam. 


\section{DAFTAR PUSTAKA}

Ansyar, Muhammad. Dasar-Dasar Pengembangan Kurikulum. Jakarta: Dirjen PT-PPLPTK Depdikbut, 1089.

Doll, Ronald C. Curriculum Improvement: Decision Making and Process. Boston: Allyn and Bacon, 1964.

Majid, Abdul dan Dian Andayani, Pendidikan Agama Islam Berbasis Kompetensi. Bandung: Remaja Rosda Karya, 2006.

Mujib, Abdul dan Jusuf Mudzakir, Ilmu Pendidikan Islam. Jakarta: Kencana Prenada Media Group, 2008.

Rais, M. Amien. Cakrawala Islam: Antara Cita dan Fakta. Bandung: Mizan, 1987.

Saad A, "Hajatuna Ila Manahij Islamiah". 02 Oktober 2015 diakses dari http://www.saaid.net/manahej/17.htm

Tafsir, Ahmad. Filsafat Pendidikan Islami. Bandung: Remaja Rosdakarya, 2010. 